\title{
German Cockroach Frass Proteases Modulate the Innate Immune Response via Activation of Protease-Activated Receptor-2
}

\author{
Scottie B. Day ${ }^{a}$ Ping Zhou a John R. Ledford ${ }^{a}$ Kristen Page ${ }^{a, b}$ \\ a Division of Critical Care Medicine, Cincinnati Children's Hospital Medical Center, and ${ }^{b}$ Department of Pediatrics, \\ University of Cincinnati, Cincinnati, Ohio, USA
}

\section{Key Words}

Allergen $\cdot$ Macrophages $\cdot$ Neutrophils $\cdot \mathrm{NF}-\mathrm{\kappa B} \cdot$ Tumor necrosis factor

\begin{abstract}
Allergen exposure can induce an early innate immune response; however, the mechanism by which this occurs has not been addressed. In this report, we demonstrate a role for the active serine proteases in German cockroach (GC) feces (frass) and protease-activated receptor (PAR)-2 in modulating the innate immune response. A single exposure of GC frass induced inflammatory cytokine production and cellular infiltration in the airways of mice. In comparison, exposure to protease-depleted GC frass resulted in diminution of inflammatory cytokine production and airway neutrophilia, but had no effect on macrophage infiltration. Selective activation of PAR-2 confirmed that PAR-2 was sufficient to induce airway inflammation. Exposure of GC frass to PAR-2deficient mice led to decreased immune responses to $G C$ frass compared to wild-type mice. Using the macrophage as an early marker of the innate immune response, we found that GC frass induced significant release of tumor necrosis factor- $\alpha$ from primary alveolar macrophages. This effect was dependent on the intrinsic proteases in GC frass. We confirmed GC frass-induced cytokine expression was mediated by activation of NF-кB and ERK in a macrophage cell line. Col-
\end{abstract}

lectively, these data suggest a central role for GC frass protease-PAR-2 activation in regulating the innate immune response through the activation of alveolar macrophages. Understanding the potential role of protease-PAR-2 activation as a danger signal or adjuvant could yield attractive therapeutic targets.

Copyright $\odot 2010$ S. Karger AG, Basel

\section{Introduction}

Allergic asthma is a chronic inflammatory disorder which is characterized by recurrent episodes of wheezing, shortness of breath, and coughing, usually in response to an environmental trigger. While the proteins from these sources trigger allergic asthma in some individuals, it is currently unclear what aspect of the allergen exerts its role in the induction of the immune response. One common denominator is that many of the known allergens contain proteolytic activity. We recently showed that removal of proteases from German cockroach (GC) feces (frass) attenuated airway hyperresponsiveness and mucin production in a mouse model of allergic airway disease [1]. It has also been shown that removal of proteases from Aspergillus fumigatus [2] decreased airway inflammation and airway hyperresponsiveness in mouse models. In addition, the proteolytic antigen Per a 10 from the Ameri- 
can cockroach [3], Epi p1 from Epicoccum purpurascens [4] and Cur 11 from Curvularia lunata [5] also regulated airway inflammation and airway hyperresponsiveness in mouse models. These data suggest a role for the intrinsic proteases in allergens in modulating allergic airway disease; however, the mechanism by which this occurs is currently unclear.

It is likely that the innate immune response contributes to the initiation of allergic disease. The first cells to encounter airborne pathogens are resident airway cells including the airway epithelium, alveolar macrophages, and dendritic cells (DCs). Many in vitro studies have shown that proteases from house dust mites (HDM), cockroaches, and fungi activate the innate immune response by inducing cytokine [interleukin (IL)- 6 and IL-8] and chemokine (GM-CSF) expression from the airway epithelium [6-9]. Alveolar macrophages are also important secretory cells, and it has been shown that exposure of primary alveolar macrophages or the alveolar macrophage cell line derived from Balb/c mice (MHS cells) to HDM induced significant tumor necrosis factor- $\alpha$ $(\mathrm{TNF} \alpha)$ production [10]. Mucosal DCs form a dense network associated with the airway epithelium and can form long extensions into the airway lumen [11]. Allergen-induced activation of DCs is well established [12]. While it is clear that allergens can directly act on the airway epithelium and alveolar macrophages in cell culture models, a role for intrinsic proteases in the initiation and regulation of the innate immune response has not been characterized in animal models.

One mechanism by which proteases may regulate immune responses is through the activation of proteaseactivated receptors (PARs). PARs are a family of seven transmembrane G-protein-coupled receptors stimulated by extracellular proteases. To date, four family members have been identified. Cleavage of an extracellular amino portion of the molecule by thrombin (for PAR-1, PAR-3, and PAR-4) or by trypsin (for PAR-2) results in a new amino terminus. The amino terminus now acts as a tethered ligand that binds to the activation site of the receptor to activate the heterotrimeric G-proteins in the cell membrane [13]. PAR-2 can also be activated, without proteolytic cleavage, using the peptides SLIGKV (human) or SLIGRL (mouse) [14]. PAR-2 has been implicated in allergic diseases and is expressed by many cells in the lung, including airway epithelial cells [15], alveolar macrophages [16], mast cells [17], and DCs [16]. Allergens, including HDM [15], mold [18], and cockroach [19], have been shown to cleave and activate PAR-2 in cell culture models. GC extract was found to specifically activate
PAR-2, but not PAR-1, PAR-3, or PAR-4, using either blocking antibodies [20] or receptor desensitization [19]. Studies in airway epithelial cell culture have shown that PAR-2 activation regulated IL-8 production [20], GMCSF and eotaxin [21], as well as mucin secretion [22], thereby suggesting a mechanism by which PAR-2 can activate the innate immune response.

In this report, we investigated the role of proteasePAR-2 activation as an important trigger for the initiation of the innate immune response in vivo. In addition, since alveolar macrophages are among the first responders to inhaled substances, we will study the role of allergen-derived proteases on macrophage-derived cytokine production. To our knowledge, the effect of allergen-derived proteases and PAR-2 on macrophage activation or the initiation of the innate immune response in vivo has not been addressed. Our study presents evidence that proteases in GC frass can induce the innate immune response in mice via the activation of PAR-2. In addition, these proteases can directly activate alveolar macrophage cytokine production by the activation of the signaling mediators NF- $\kappa \mathrm{B}$ and extracellular regulated kinase (ERK). Together our data implicate an important role for allergenderived proteases in the initiation of the innate immune response and may further suggest a mechanism by which cockroaches produce a potent allergen.

\section{Materials and Methods}

\section{Cockroach Frass}

The fecal remnants (frass) from one cage of German cockroaches were transferred to a sterile container and stored at $4^{\circ} \mathrm{C}$. GC frass was resuspended in PBS (divalent free; Gibco/Invitrogen, Carlsbad, Calif., USA) made with endotoxin-free double-distilled water $\left(2 \mathrm{~h}\right.$ at $4^{\circ} \mathrm{C}$ while rocking). Extracts were centrifuged to remove debris $\left(13,000 \mathrm{~g}\right.$ for $5 \mathrm{~min}$ at $\left.4^{\circ} \mathrm{C}\right)$, supernatants harvested, and total protein was measured using the Bio-Rad Protein Assay Dye (Bio-Rad, Hercules, Calif., USA). To inhibit protease activity, frass was pretreated with aprotinin (a specific inhibitor of serine proteases; $10 \mu \mathrm{g} / \mathrm{ml}$ for $30 \mathrm{~min}$ at $37^{\circ} \mathrm{C}$ ) prior to use. The same concentration of aprotinin was added to PBS and used as a control. Protease activity was determined using the Azocoll assay as previously described [7]. GC frass was determined to contain $19 \mu \mathrm{g}$ protease activity/mg frass and aprotinin treatment inhibited $85 \%$ of the protease activity [23] and will hence be referred to as protease-depleted GC frass.

\section{Animals}

Six-week-old female Balb/c and PAR-2-deficient mice were obtained from the Jackson Laboratory (Bar Harbor, Me., USA). The PAR-2-deficient mice were on the C57BL/6 background, which has been documented to be the least responsive to allergen exposure via the airways [24], thus necessitating the need to backcross 
these mice onto the Balb/c background. These studies conformed to the principles for laboratory animal research outlined by the Animal Welfare Act and the Department of Health, Education, and Welfare (National Institutes of Health). These studies were approved by the Institutional Animal Care and Use Committee of the Cincinnati Children's Hospital Medical Center.

\section{Mouse Challenge Protocol}

Mice were anesthetized with ketamine $(45 \mathrm{mg} / \mathrm{kg}) /$ xylazine $(8 \mathrm{mg} / \mathrm{kg})$ prior to PBS or GC frass $(40 \mu \mathrm{g} / 40 \mu \mathrm{l})$ exposure by a single inhalation as previously described [25]. For direct PAR-2 activation, we administered via intratracheal inhalation PAR-2activating peptide (PAR-2-AP; SLIGRL- $\mathrm{NH}_{2}$ ), or a scrambled control peptide (PAR-2-CP; LSIGRL-NH $\mathrm{N}_{2}$ ) obtained from Peptides International (Louisville, Ky., USA) at a concentration of 400 $\mu \mathrm{g} / 40 \mu \mathrm{l}$ in PBS. Eighteen hours later, mice were given a lethal dose of sodium pentobarbital.

\section{Assessment of Airway Inflammation}

Lungs were lavaged with $1 \mathrm{ml}$ of Hanks' balanced salt solution without calcium or magnesium. The lavage fluid was centrifuged ( $300 \mathrm{~g}$ for $10 \mathrm{~min}$ ), and the supernatant was removed for cytokine analysis and immediately stored at $-80^{\circ} \mathrm{C}$. The cell pellet was resuspended in $1 \mathrm{ml}$ of $10 \%$ fetal bovine serum in PBS. Total cell numbers were counted on a hemocytometer; $200 \mu$ l of the resuspended bronchoalveolar lavage (BAL) cells were centrifuged onto a microscope slide using the Cytospin II centrifuge (Shandon Thermo, Waltham, Mass., USA), for $10 \mathrm{~min}$ at $64 \mathrm{~g}$ at room temperature. Once dried, cells were stained with Diff-Quick (Thermo Electron, Pittsburg, Pa., USA) solution for differential cell counting, and 500-700 cells were counted per slide. BAL fluid was analyzed for keratinocyte-derived chemokine (KC) and TNF $\alpha$ according to the manufacturer's specifications (R\&D Systems, Minneapolis, Minn., USA).

\section{Cell Culture}

BAL cells from naïve Balb/c or PAR-2-deficient mice were seeded onto 12 -well plates $\left(5 \times 10^{5}\right.$ cells $/ \mathrm{ml}, 500 \mu \mathrm{l} /$ well $)$ and incubated for $2 \mathrm{~h}$ at $37^{\circ} \mathrm{C}$ and $5 \% \mathrm{CO}_{2}$. Residual adherent BAL macrophages ( $>95 \%$ viability) were cultured in Dulbecco's modified Eagle's medium (DMEM) supplemented with $2 \%$ fetal bovine serum and penicillin/streptomycin. A mouse alveolar macrophage cell line, MHS, purchased from American Type Culture Collection (Manassas, Va., USA) was cultured in DMEM (Invitrogen) supplemented with $10 \%$ fetal bovine serum and penicillin/streptomycin. Cells $\left(1 \times 10^{6}\right.$ cells $/ \mathrm{ml}, 1 \mathrm{ml} /$ well $)$ were seeded onto 6 -well plates and grown to confluence at $37^{\circ} \mathrm{C}$ and $5 \% \mathrm{CO}_{2}$. Once confluent, cells were rinsed with PBS $(2 \times 1 \mathrm{ml})$, and $1 \mathrm{ml}$ DMEM without serum was added per well. In all cases, cells were treated with PBS, aprotinin-pretreated PBS, GC frass $(1 \mu \mathrm{g} / \mathrm{ml})$, and protease-depleted GC frass $(1 \mu \mathrm{g} / \mathrm{ml})$. In some cases, cells were pretreated with either dimethyl sulfoxide, isohelenin $(30 \mu \mathrm{M}$; EMD Biosciences, San Diego, Calif., USA), PD98059 (30 $\mu$ M; Cell Signaling Technology, Danvers, Mass., USA), and SB202190 (10 $\mu \mathrm{M}$; Calbiochem, La Jolla, Calif., USA) for $1 \mathrm{~h}$ prior to treatment. Supernatants were harvested $18 \mathrm{~h}$ after treatment, clarified by centrifugation $(13,000 \mathrm{~g})$ to remove any cellular debris, and analyzed for TNF $\alpha$ by ELISA (R\&D Systems).

Allergen-Derived Proteases and PAR-2

Modulate Innate Immunity
Electrophoretic Mobility Shift Assay

MHS cells $\left(1 \times 10^{6}\right.$ cells $/ \mathrm{ml}, 10 \mathrm{ml}$ per $100-\mathrm{mm}^{2}$ cell culture dish) were grown to confluence. Once confluent, cells were rinsed twice with PBS and starved with $5 \mathrm{ml}$ of DMEM without serum overnight. Cells were then treated with GC frass $(1 \mu \mathrm{g} / \mathrm{ml})$ for $4 \mathrm{~h}$. Nuclear proteins were isolated as previously described [26]. Protein concentrations were determined by Bio-Rad protein assay and stored at $-70^{\circ} \mathrm{C}$ until use. The oligonucleotide probe encoding the consensus sequence of NF-кB or AP-1 (Santa Cruz, Santa Cruz, Calif., USA) was labeled with $\left[\gamma_{-}{ }^{32} \mathrm{P}\right]$ ATP using T4 polynucleotide kinase (Invitrogen) and purified in a MicroBiospin chromatography column. The gel was run using $10 \mu \mathrm{g}$ of nuclear protein as previously described [27]. Gels were transferred to Whatman $3 \mathrm{M}$ paper, dried under vacuum at $80^{\circ} \mathrm{C}$ for $1 \mathrm{~h}$, and exposed using a Phosphoimager.

\section{Immunoblot Analysis}

MHS cells $\left(1 \times 10^{6}\right.$ cells $/ \mathrm{ml}, 1 \mathrm{ml} /$ well $)$ were plated into 6 -well plates and grown to confluence at $37^{\circ} \mathrm{C}$ and $5 \% \mathrm{CO}_{2}$. Once confluent, cells were rinsed with PBS $(2 \times 1 \mathrm{ml})$, and $1 \mathrm{ml}$ DMEM without serum was added per well for $18 \mathrm{~h}$. Cells were then treated with GC frass $(1 \mu \mathrm{g} / \mathrm{ml})$ for $15,30,45,60$, or $90 \mathrm{~min}$. Following the incubation, samples were extracted in a lysis buffer containing $50 \mathrm{~mm}$ Tris (pH 7.5), $40 \mathrm{~mm} \beta$-glycerophosphate, $100 \mathrm{mM} \mathrm{NaCl}$, $2 \mathrm{~mm}$ EDTA, $50 \mathrm{~mm} \mathrm{NaF}, 200 \mu \mathrm{M} \mathrm{Na} \mathrm{VO}_{4}, 200 \mu \mathrm{M}$ PMSF, and $1 \%$ Triton X-100 on ice for $10 \mathrm{~min}$. Insoluble materials were removed by centrifugation $\left(13,000 \mathrm{~g}\right.$ for $10 \mathrm{~min}$ at $\left.4^{\circ} \mathrm{C}\right) ; 50 \mu \mathrm{g}$ of each sample were loaded onto a $10 \%$ SDS-polyacrylamide gel. The gel was then transferred to nitrocellulose, which was then blocked in $5 \%$ milk/TBS- $0.1 \%$ Tween 20 overnight at $4^{\circ} \mathrm{C}$. After a 1-hour incubation with a 1:1,000 dilution of anti-I $\kappa \mathrm{B} \alpha$ antibody (clone C21; Santa Cruz), $\beta$-actin (clone C4; Santa Cruz), anti-phosphoERK antibody (Thr202/Tyr204; Santa Cruz), or ERK antibody (clone MK12; Millipore, Billerica, Mass., USA) at room temperature, the nitrocellulose was washed in TBS-0.1\% Tween 20 , and $1: 10,000$ dilution of the appropriate secondary antibody was added (goat anti-rabbit IgG or goat anti-mouse IgG, H\&L chain-specific peroxidase conjugate, Calbiochem/EMD, Gibbstown, N.J., USA) for $1 \mathrm{~h}$ at room temperature. Following 4 rinses with TBS$0.1 \%$ Tween 20 , signals were amplified and visualized using enhanced chemiluminescence Western blot detection reagent (GE Healthcare, Piscataway, N.J., USA).

\section{Statistical Analysis}

When applicable, statistical significance was assessed by oneway analysis of variance (ANOVA). Differences identified by ANOVA were pinpointed by Student-Newman-Keuls' multiple range test.

\section{Results}

\section{Serine Proteases Regulate the Innate Immune \\ Response to GC Frass Inhalation}

To address the role of active serine proteases in modulating the innate immune response, we performed a single intratracheal inhalation of PBS, aprotinin, GC frass, or protease-depleted GC frass in naïve $\mathrm{Balb} / \mathrm{c}$ mice. $\mathrm{BAL}$ 

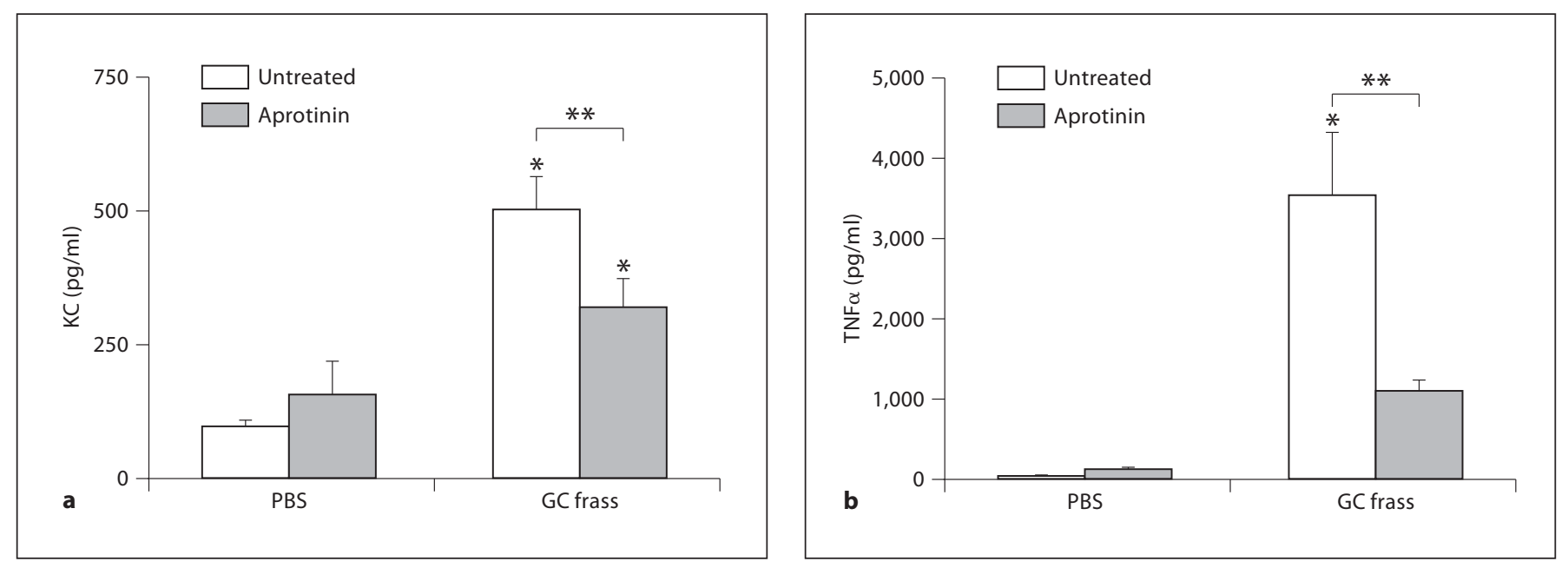

Fig. 1. GC frass-associated proteases partially regulated TNF $\alpha$ and $\mathrm{KC}$ expression in the airways of mice. Balb/c mice were given a single intratracheal inhalation of PBS, aprotinin-treated PBS, GC frass (40 $\mu \mathrm{g} / 40 \mu \mathrm{l})$, or protease-depleted GC frass ( $40 \mu \mathrm{g} / 40 \mu \mathrm{l}) ; 18 \mathrm{~h}$ later, BAL fluid was harvested, clarified, and cytokines were analyzed by ELISA. Means \pm SEM ( $n=5-7$ mice per group). a KC $\left({ }^{*} \mathrm{p}<0.004\right.$ vs. control; ${ }^{* *} \mathrm{p}=0.005$ vs. GC frass). b $\mathrm{TNF} \alpha\left({ }^{*} \mathrm{p}<0.001\right.$ vs. control; ${ }^{* *} \mathrm{p}<0.001$ vs. GC frass $)$.

Table 1. Differential cell count in BAL fluid of wild-type mice following exposure to GC frass or protease-depleted GC frass

\begin{tabular}{|c|c|c|c|c|c|}
\hline & $\begin{array}{l}\text { Macro- } \\
\text { phages }\end{array}$ & $\begin{array}{l}\text { Epithelial } \\
\text { cells }\end{array}$ & $\begin{array}{l}\text { Eosin- } \\
\text { ophils }\end{array}$ & $\begin{array}{l}\text { Neutro- } \\
\text { phils }\end{array}$ & $\begin{array}{l}\text { Lympho- } \\
\text { cytes }\end{array}$ \\
\hline PBS & $0.2 \pm 0.1$ & $1.0 \pm 0.1$ & 0 & 0 & 0 \\
\hline PBS-Ap & $9.1 \pm 2.4$ & $5.5 \pm 1.5$ & 0 & $7.7 \pm 2.7$ & 0 \\
\hline GC frass & $10.7 \pm 1.6^{*}$ & $6.4 \pm 3.3$ & 0 & $79.9 \pm 14.6^{*}$ & $2.8 \pm 1.1^{*}$ \\
\hline GC frass-Ap & $11.9 \pm 3.5^{*}$ & $5.3 \pm 2.4$ & 0 & $39.9 \pm 9.9^{* * * *}$ & * $2.3 \pm 0.6^{*}$ \\
\hline
\end{tabular}

Wild-type (Balb/c) mice were exposed to a single inhalation of PBS $(40 \mu \mathrm{l})$, and PBS pretreated with aprotinin (PBS-Ap), GC frass $(40 \mu \mathrm{g} / 40 \mu \mathrm{l})$, or protease-depleted GC frass (GC frass-Ap); $18 \mathrm{~h}$ later, BAL fluid was harvested and differential cell counts performed. These data represent 5-7 mice per group and are expressed as means \pm SEM of cell numbers $\times 10^{4}$ and statistical significance was determined by ANOVA.

${ }^{*} \mathrm{p}<0.05 \mathrm{vs}$. PBS. Only neutrophils were significantly decreased in GC frass-Ap compared to GC frass ( $\left.{ }^{* *} \mathrm{p}=0.01\right)$.

fluid was harvested $18 \mathrm{~h}$ later and analyzed for the expression of the inflammatory cytokines TNF $\alpha$ and $\mathrm{KC}$ as well as cellular infiltration. GC frass significantly induced the release of the inflammatory cytokines TNF $\alpha$ and $\mathrm{KC}$ into the airways (fig. 1). Importantly, exposure to proteasedepleted GC frass significantly reduced the inflammatory response, as indicated by significantly decreased lev- els of TNF $\alpha$ and KC in the airways. Next we determined the level of cellular infiltration into the airways of these mice. Inhalation of GC frass significantly increased the recruitment of neutrophils, macrophages, and lymphocytes into the lungs of mice (table 1). There was a significant reduction in the level of newly migrated neutrophils into the airways of mice exposed to protease-depleted GC frass, likely due to the decrease in $\mathrm{KC}$ levels. Interestingly, removal of protease from GC frass had no effect on alveolar macrophage recruitment. Together, these data suggest that the intrinsic proteases in GC frass regulate cytokine and chemokine production in vivo leading to decreased neutrophil migration into the airways.

\section{Selective Activation of PAR-2 Increased the Innate Immune Response}

To determine if PAR-2 was sufficient to mediate an innate immune response, we performed a single intratracheal inhalation of PAR-2-AP or PAR-2-CP. These peptides activate PAR-2 by bypassing the requirement for proteolytic cleavage. Importantly, we found that a single exposure to PAR-2-AP, but not PAR-2-CP, increased TNF $\alpha$ and KC expression (fig. 2). In addition, PAR-2-AP induced a significant increase in neutrophils and macrophages compared to PBS and PAR-2-CP (table 2). These data confirm that selective activation of PAR-2 is sufficient to induce an innate immune response in vivo. 

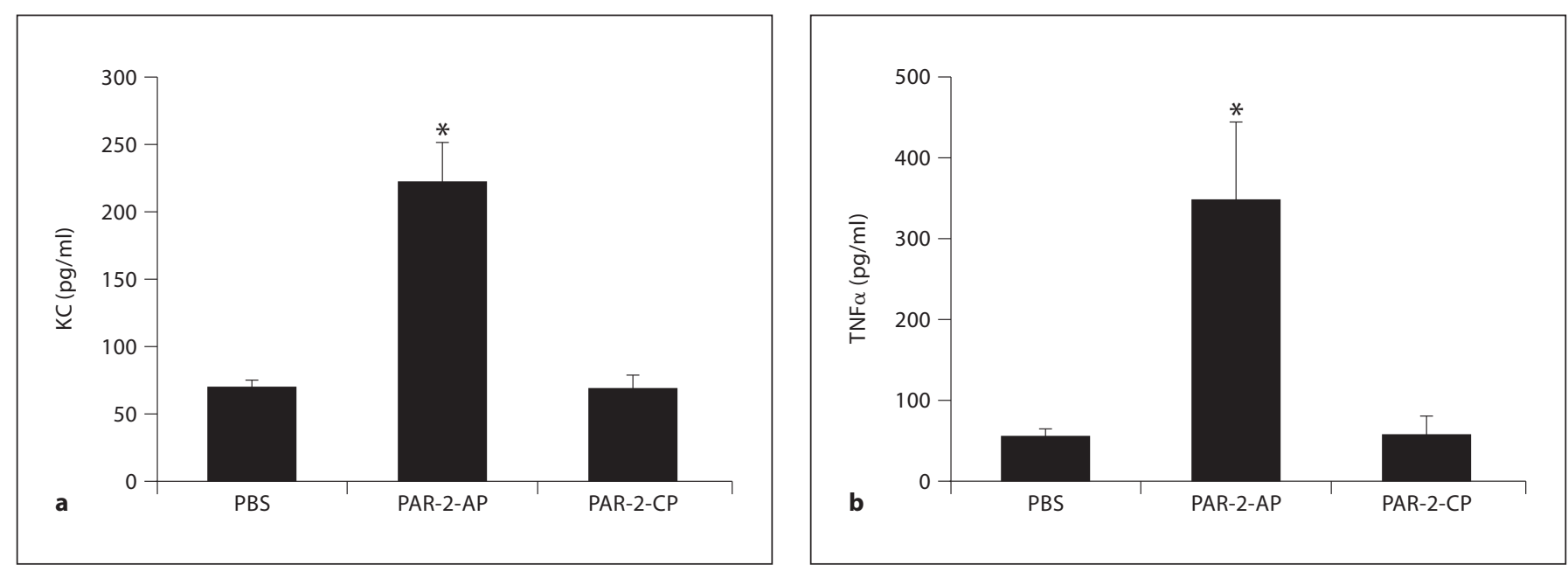

Fig. 2. Selective activation of PAR-2 increased KC and TNF $\alpha$ expression in the airways of mice. Naïve wild-type mice were given a single intratracheal inhalation of PBS, PAR-2-AP, or PAR-2-CP; 18 h later, BAL fluid was harvested, clarified, and cytokines were analyzed by ELISA. Means \pm SEM ( $=4-6$ mice per group). a KC levels ( ${ }^{*} \mathrm{p}<0.001$ vs. PBS control). b TNF $\alpha$ levels ( ${ }^{*} \mathrm{p}<0.001$ vs. PBS control).

Serine Proteases Regulate the Innate Immune Response to GC Frass Inhalation in a

\section{PAR-2-Dependent Manner}

To address the role of PAR-2 in regulating the innate immune response to an inhaled allergen, we compared a single exposure of GC frass in wild-type and PAR-2-deficient mice. Exposure to GC frass induced a significant increase in $\mathrm{TNF} \alpha$ and $\mathrm{KC}$ expression in the BAL fluid, which was significantly decreased in PAR-2-deficient mice (fig. 3). Concurrent with a decrease in KC, the major chemoattractant for neutrophils, we detect less neutrophil infiltration in PAR-2-deficient mice compared with wild-type mice following GC frass inhalation (table 3). Again, macrophage and lymphocyte migration were independent of protease-PAR-2 activation. Together, these data confirm that GC frass proteases play a role in modulating the early innate immune response through the activation of PAR-2.

\section{GC Frass Regulates TNF $\alpha$ Release from Alveolar \\ Macrophages}

Since macrophages express PAR-2 [28] and are a significant source of TNF $\alpha$, a crucial cytokine in the induction of the innate immune response, we focused the rest of this study on the regulation of $\mathrm{TNF} \alpha$ by cockroach proteases. Naïve mice were lavaged and alveolar macrophages were isolated and cultured for $18 \mathrm{~h}$ in the presence
Table 2. Differential cell count in BAL fluid of wild-type mice exposed to PAR peptides

\begin{tabular}{llllll}
\hline & $\begin{array}{l}\text { Macro- } \\
\text { phages }\end{array}$ & $\begin{array}{l}\text { Epithelial } \\
\text { cells }\end{array}$ & $\begin{array}{l}\text { Eosin- } \\
\text { ophils }\end{array}$ & $\begin{array}{l}\text { Neutro- } \\
\text { phils }\end{array}$ & $\begin{array}{l}\text { Lympho- } \\
\text { cytes }\end{array}$ \\
\hline PBS & $0.3 \pm 0.03$ & $0.1 \pm 0.04$ & 0 & $0.06 \pm 0.03$ & 0 \\
PAR-2-AP & $2.6 \pm 1.8^{*}$ & $0.3 \pm 0.1$ & 0 & $2.0 \pm 0.6^{*}$ & 0 \\
PAR-2-CP & $0.5 \pm 0.1^{* *}$ & $0.1 \pm 0.6$ & 0 & $0.3 \pm 0.1^{* *}$ & 0
\end{tabular}

Wild-type (Balb/c) mice were exposed to a single inhalation of PBS $(40 \mu \mathrm{l})$, the PAR-2-AP SLIGRL $(400 \mu \mathrm{g} / 40 \mu \mathrm{l})$ or the PAR-2-CP LSIGRL $(400 \mu \mathrm{g} / 40 \mu \mathrm{l}) ; 18 \mathrm{~h}$ later, BAL fluid was harvested and differential cell counts performed. These data represent 4-6 mice per group and are expressed as means \pm SEM of cell numbers $\times 10^{4}$ and statistical significance was determined by ANOVA.

Cell counts were statistically significant between PAR-2-AP and PBS in the wild type $\left({ }^{*} \mathrm{p}<0.05\right)$ and PAR-2-CP compared to PAR2-AP $\left({ }^{* *} \mathrm{p}<0.05\right)$.

of GC frass or protease-depleted GC frass. We found that GC frass significantly increased TNF $\alpha$ production from alveolar macrophages and removal of the active proteases significantly attenuated TNF $\alpha$ production (fig. 4a). Next, we exposed alveolar macrophages from wild-type and PAR-2-deficient mice to GC frass and the production of $\mathrm{TNF} \alpha$ was measured. A significant decrease in TNF $\alpha$ 

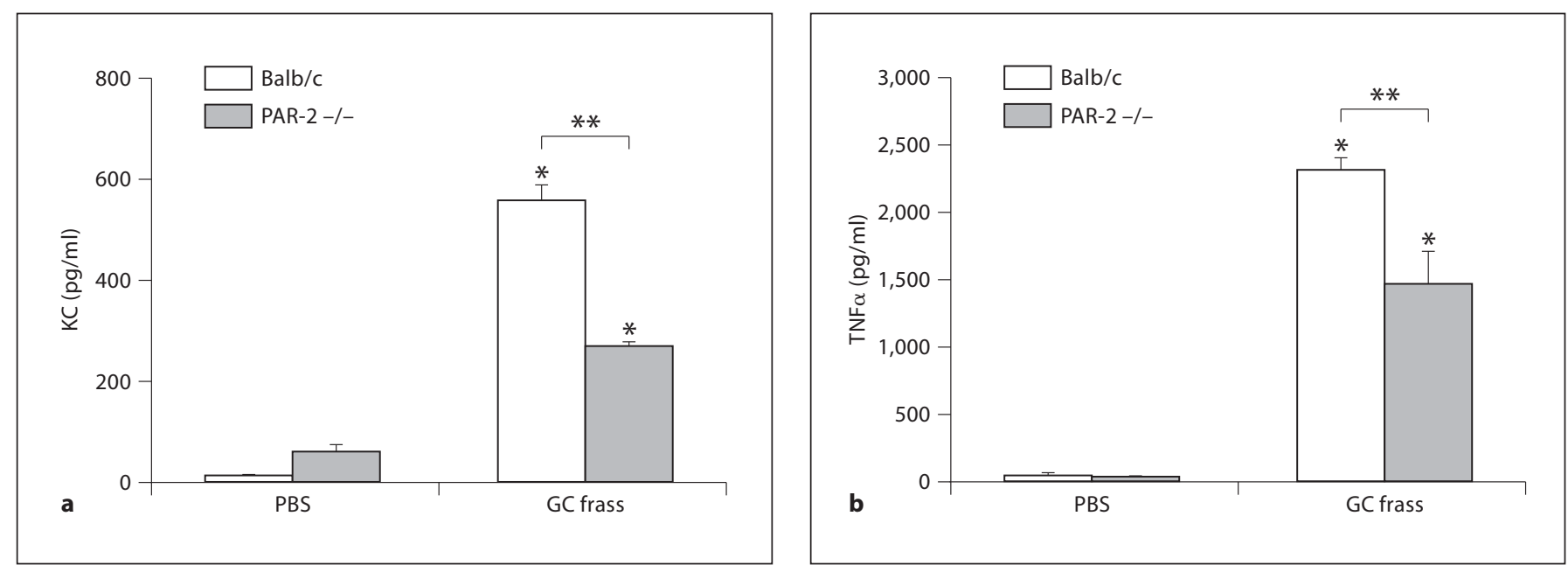

Fig. 3. PAR-2 regulated $\mathrm{KC}$ and $\mathrm{TNF} \alpha$ expression in vivo. PAR-2-deficient mice were given a single intratracheal inhalation of PBS or GC frass $(40 \mu \mathrm{g} / 40 \mu \mathrm{l}) ; 18 \mathrm{~h}$ later, BAL fluid was harvested, clarified, and cytokines were analyzed by ELISA. Means $\pm \operatorname{SEM}\left(\mathrm{n}=4-6\right.$ mice per group). a $\mathrm{KC}\left({ }^{*} \mathrm{p}<0.001\right.$ vs. PBS control; ${ }^{* *} \mathrm{p}=0.001$ vs. GC frass). b TNF $\alpha{ }^{*} \mathrm{p}<0.001$ vs. PBS control; ${ }^{* *} \mathrm{p}<0.001$ vs. GC frass $)$.

Table 3. Differential cell count in BAL fluid of wild-type (w.t.) and PAR-2-deficient mice following a single exposure to GC frass

\begin{tabular}{llllll}
\hline & Macrophages & Epithelial cells & Eosinophils & Neutrophils & Lymphocytes \\
\hline w.t. PBS & $0.8 \pm 0.1$ & $1.0 \pm 0.3$ & 0 & $0.2 \pm 0.2$ & 0 \\
PAR-2-/- PBS & $0.8 \pm 0.2$ & $1.0 \pm 0.3$ & 0 & $0.4 \pm 0.2$ & $0.1 \pm 0.01$ \\
w.t. GC frass & $9.0 \pm 1.8^{*}$ & $4.7 \pm 2.4$ & 0 & $69.5 \pm 4.0^{*}$ & $2.5 \pm 1.0^{*}$ \\
PAR-2-/- GC frass & $8.3 \pm 2.3^{* *}$ & $5.9 \pm 2.4$ & 0 & $52.7 \pm 4.2^{* * * * *}$ & $3.5 \pm 0.3^{* *}$ \\
\hline
\end{tabular}

Wild-type (Balb/c) and PAR-2-deficient mice were exposed to a single inhalation of PBS (40 $\mu$ l) or GC frass $(40 \mu \mathrm{g} / 40 \mu \mathrm{l}) ; 18 \mathrm{~h}$ later, BAL fluid was harvested and differential cell counts performed. These data represent 4-6 mice per group and are expressed as means \pm SEM of cell numbers $\times 10^{4}$ and statistical significance was determined by ANOVA.

Cell counts were statistically significant between GC frass and PBS in the wild-type $\left({ }^{*} \mathrm{p}<0.05\right)$ and PAR-2deficient mice $\left.{ }^{* *} \mathrm{p}<0.05\right)$. Only neutrophils were significantly decreased in PAR-2 mice compared to wild-type mice following GC frass exposure $\left({ }^{* *} \mathrm{p}=0.005\right)$.

release from PAR-2-deficient primary alveolar macrophages compared to wild-type alveolar macrophages (fig. 4b) was detected. These data confirm that GC frass activation of PAR-2 leads to TNF $\alpha$ release from alveolar macrophages.

\section{GC Frass-Induced TNF $\alpha$ Expression Is Dependent on}

$N F-\kappa B$ and ERK Activation in Macrophages

To address the signaling aspect of cytokine production, we switched to a murine alveolar macrophage cell line, MHS cells. We used a battery of chemical inhibitors to determine whether specific kinases were required for the GC frass activation of TNF $\alpha$. We found that inhibition of NF- $\mathrm{B}$ (isohelenin), and inhibition of ERK signaling (PD98059), but not the inhibition of p38 (SB202190), significantly attenuated GC frass-induced TNF $\alpha$ production (fig. 5a). To confirm the role of NF- $\kappa$ B in mediating this response, we asked whether $\mathrm{GC}$ frass induced the degradation of $\mathrm{I} \kappa \mathrm{B} \alpha$, a major step in NF- $\kappa \mathrm{B}$ activation. MHS cells were cultured in the presence or absence of GC 

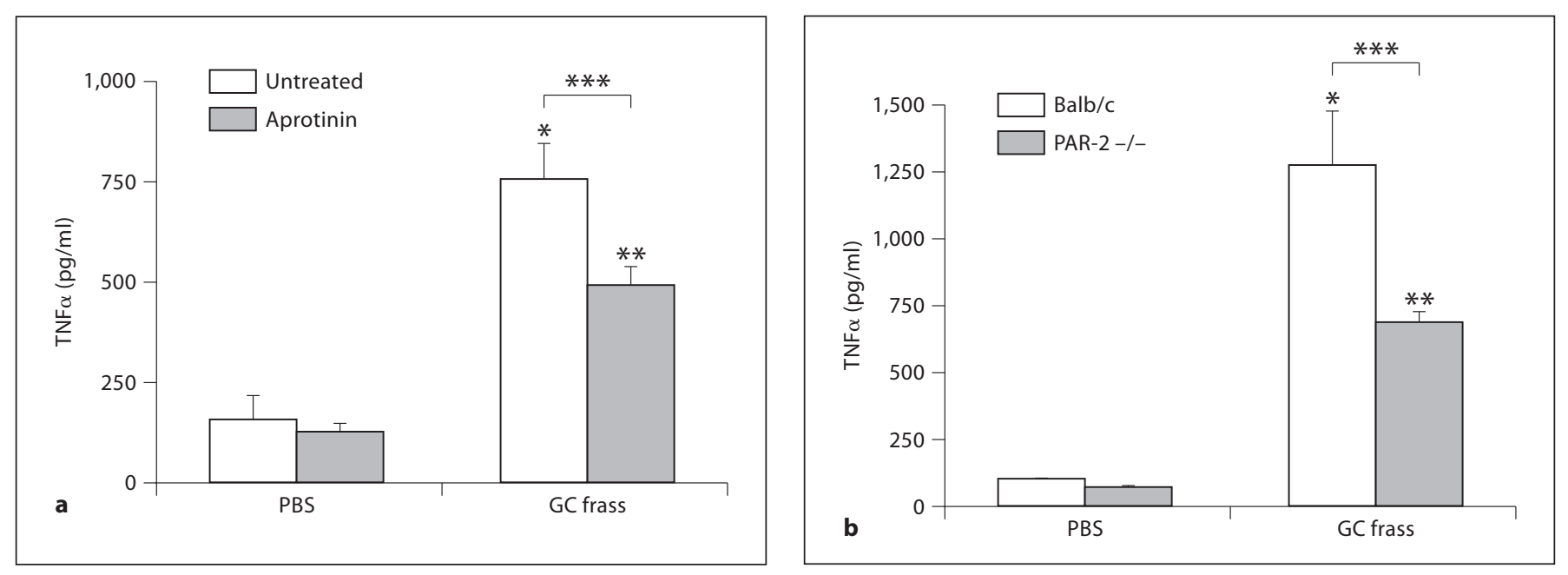

Fig. 4. GC frass proteases and PAR-2 mediate TNF $\alpha$ release from alveolar macrophages. a BAL fluid from naïve $\mathrm{Balb} / \mathrm{c}$ mice was cultured and treated with PBS, aprotinin-treated PBS, GC frass $(1 \mu \mathrm{g} / \mathrm{ml})$, or protease-depleted GC frass $(1 \mu \mathrm{g} / \mathrm{ml})$ for $18 \mathrm{~h}$. Cell supernatants were harvested, clarified and analyzed for TNF $\alpha$ by ELISA. ${ }^{*} \mathrm{p}<0.001$ and ${ }^{* *} \mathrm{p}=0.002$ vs. control; ${ }^{* * *} \mathrm{p}=0.004$ vs. GC frass, $\mathrm{n}=5$ separate experiments. b BAL fluid from Balb/c and PAR-2-deficient mice were cultured and treated with PBS or GC frass $(1 \mu \mathrm{g} / \mathrm{ml}) .{ }^{*} \mathrm{p}<0.001$ and ${ }^{* *} \mathrm{p}=0.008$ vs. PBS; ${ }^{* *} \mathrm{p}=0.004$ vs. GC frass, $\mathrm{n}=3$ separate experiments.

frass for increasing amounts of time, and a Western blot was performed for I $\mathrm{B} \alpha$. GC frass induced a time-dependent decrease in I $\mathrm{K} B \alpha$ levels (fig. $5 \mathrm{~b}$ ). To confirm that $\mathrm{I} \kappa \mathrm{B} \alpha$ degradation leads to NF- $\kappa \mathrm{B}$ translocation to the nucleus, we isolated the nuclear extracts of cells $4 \mathrm{~h}$ following treatment and studied NF- $\kappa \mathrm{B}-\mathrm{DNA}$ binding using an electrophoretic mobility shift assay (EMSA). We found that NF- $\kappa B$ translocated to the nucleus and bound to DNA (fig. 5d). We also confirmed that GC frass induced ERK phosphorylation by Western blot (fig. 5c). Since the transcription factor AP-1 is a downstream target of ERK, we asked whether GC frass activated AP-1. Nuclear extracts were analyzed for AP-1-DNA binding by EMSA. We found that GC frass induced AP-1-DNA binding in MHS cells, and this was significantly diminished when cells were treated with protease-depleted GC frass (fig. 5c). Together these data suggest that GC frass can induce a robust signaling pathway consisting of activation of the transcription factors NF- $\kappa \mathrm{B}$ and $\mathrm{AP}-1$ leading to $\mathrm{TNF} \alpha$ and $\mathrm{KC}$ cytokine expression.

\section{Discussion}

Important in the induction of the innate immune response are the inflammatory cytokines $\mathrm{TNF} \alpha$ and $\mathrm{KC}$ (the mouse homolog of human IL-8) and cellular recruit- ment of neutrophils and macrophages into the airways. Our finding that GC frass protease-PAR-2 activation regulated the innate immune response in vivo is novel and enhances our understanding of the role for proteases in mediating the innate immune response. Alveolar macrophages were shown to exhibit more intense staining for PAR-2 expression than other inflammatory cells in the airways [28], and therefore we focused on these cells as potential mediators of the early innate immune response. Our data show that the proteases in a common allergen could mediate a signal transduction pathway leading to increased production of $\mathrm{TNF} \alpha$ and $\mathrm{KC}$ via activation of PAR-2. To our knowledge, this is the first report studying the role of allergen-derived proteases and the activation of PAR-2 in mediating the early innate immune response in an animal model.

Alveolar macrophages are abundant in the alveolar spaces and are pivotal not only in the elimination of foreign substances but also the initiation of the inflammatory process. Alveolar macrophages have been shown to induce cytokines important in the innate immune response. For example, human alveolar macrophages were shown to induce TNF $\alpha$ and IL- 8 release following exposure to rhinovirus [29]. Treatment of MHS cells with A. fumigatus spores elicited increased TNF $\alpha$, MIP- $1 \alpha$, MIP-1 $\beta$, and MCP-1 mRNA within $6 \mathrm{~h}$ [30]. A. fumigatus was also shown to induce TNF $\alpha$ cytokine expression in 


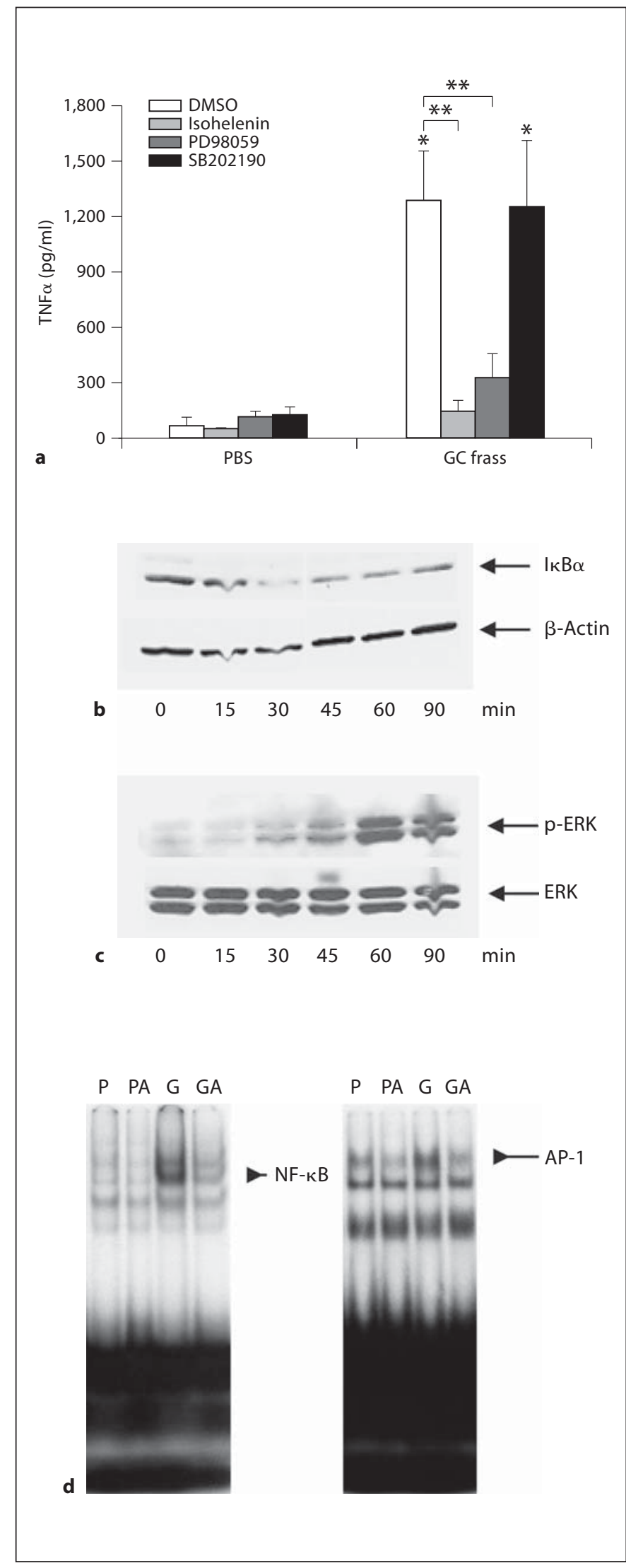

502 alveolar macrophages through the activation of ERK [31]. Alveolar macrophages are the most prevalent cells in the human airspace both in normal subjects and in asthmatics. Importantly, following antigen challenge, the increase in alveolar macrophages exceeds that of eosinophils, neutrophils, or lymphocytes [32]. Alveolar macrophage function was shown to be compromised in patients with poorly controlled asthma with a reduction in their ability to phagocytose [33]. In addition, in a study of asthmatic subjects, functional changes in the alveolar macrophages were identified, including an altered phenotype, enhanced antigen presentation, and an increased production of secretory products $[34,35]$. A recent report has suggested a direct link between the number of alveolar macrophages in the lung and allergic airway inflammation in mice [36]. Thus, it is likely that the alveolar macrophage plays an important role not only in the induction of an innate immune response, but may also influence the adaptive immune response leading to asthma.

The concept that intrinsic allergen-derived proteases and PAR-2 may have direct immunomodulatory roles in vitro has been borne out in a number of studies. Allergenderived proteases have been shown to modulate cytokine expression from airway epithelial cells [6-8, 18, 37]. HDM protease Der $\mathrm{p} 1$ was shown to increase permeability of the bronchial epithelium by cleaving the tight junction adhesion protein occludin [37] suggesting a mechanism for increased exposure of the allergen to DC. Human $\beta$-defensin and CCL20, both of which are important mediators of innate immunity, were decreased in PAR-2-de-

Fig. 5. GC frass induction of TNF $\alpha$ is dependent on NF- $\mathrm{B}$ activation in macrophages. a MHS cells were pretreated with isohelenin $(30 \mu \mathrm{M})$, PD98059 $(30 \mu \mathrm{M})$, SB202190 $(10 \mu \mathrm{M})$, or DMSO for $1 \mathrm{~h}$ prior to treatment with GC frass $(1 \mu \mathrm{g} / \mathrm{ml})$. Means \pm SEM for 4 separate experiments $\left({ }^{*} \mathrm{p}<0.001 \mathrm{vs}\right.$. PBS; ${ }^{* *} \mathrm{p}=0.002$ and *** $\mathrm{p}=0.004$ vs. GC frass). b MHS cells were treated with GC frass $(1 \mu \mathrm{g} / \mathrm{ml})$ for different times as indicated (0-90 min). Cell lysates were harvested and analyzed for I $\mathrm{B} \alpha$ expression by Western blot. Membrane was stripped and reprobed for $\beta$-actin expression. c Lysates from $\mathbf{b}$ were analyzed by Western blot for phospho (p)-ERK, and membrane was subsequently stripped and reprobed for ERK. The data shown are representative of 3 separate experiments. d MHS cells were treated with PBS (P), aprotinintreated PBS (PA), GC frass (G), or aprotinin-treated GC frass (GA) for $4 \mathrm{~h}$ and nuclear extracts were isolated and analyzed by EMSA. The oligonucleotide probe for the left gel is NF- $\kappa \mathrm{B}$ and AP-1 for the right gel. The data shown are representative of 2 separate experiments. 
ficient gingival epithelial cells following treatment with Porphyromonas gingivalis [38]. Thus, allergen-derived proteases through PAR-2 activation may serve as a link between the innate and adaptive immune response. HDM was also shown to activate chloride channels via PAR-2 in human airway epithelial cells [39]. Activation of PAR-2 with papain, trypsin, or fungi (Alternaria) induced airway epithelial cell expression of thymic stromal lymphopoietin [40], which is thought to activate DCs to polarize naïve T cells to Th2 cells. Our study provides in vivo as well as in vitro evidence that GC frass proteases can activate the innate immune response and provides evidence that alveolar macrophages can respond to allergen-derived proteases via PAR-2.

In this work, we focused specifically on the role of the allergen-derived protease and PAR-2 on activation of the alveolar macrophage; however a direct role for this protease on the airway epithelium as well as macrophageepithelial cell interactions should also be considered. We did not directly study the role of the protease-PAR-2 activation in the mouse airway epithelium, but we have previously shown that GC extract proteases act through PAR-2 to mediate IL-8 cytokine production from human airway epithelial cells [20]. Lung macrophage-airway epithelial cell interactions may work in synergy to promote inflammatory responses. Interestingly, it was shown that various types of particulate matter induced cytokine re- lease from epithelial cells but not alveolar macrophages; however, co-culture of alveolar macrophages with epithelial cells induced a synergistic increase in cytokine release (TNF $\alpha$ and MIP-2) which was contact dependent [41]. The understanding that GC frass proteases act directly on alveolar macrophages as well as airway epithelium alone is the first step in understanding the more complex role of macrophage-epithelial interactions and needs to be investigated further in the future.

It is still unclear exactly what makes an allergen able to shift from tolerance to disease; however, our studies clearly show that protease-PAR-2 activation regulates the innate immune response in vivo. Since the innate immune response can activate adaptive immunity, proteases and the activation of PAR-2 may play an important role as an adjuvant in the initiation of allergic airway disease. Furthermore, the discovery of the protease-PAR-2 mechanism at the forefront of the immune response promotes PAR-2 as novel therapeutic targets for the treatment of inflammation.

\section{Acknowledgments}

This work was supported by National Institutes of Health grants [HL075568 (K.P.) and T32 GM 088478-16 (S.B.D.)] and an American Medical Association Seed Research grant (S.B.D.).

\section{References}

-1 Page K, Lierl K, Herman N, Wills-Karp M: Differences in susceptibility to German cockroach frass and its associated proteases in induced allergic inflammation in mice. Respir Res 2007;8:91.

$\checkmark 2$ Kheradmand F, Kiss A, Xu J, Lee SH, Kolattukudy PE, Corry DB: A protease-activated pathway underlying Th2 cell type activation and allergic lung disease. J Immunol 2002; 169:5904-5911.

3 Sudha VT, Arora N, Singh BP: Serine protease activity of Per a 10 augments allergen-induced airway inflammation in a mouse model. Eur J Clin Invest 2009;39:507-516.

$\checkmark 4$ Kukreja N, Sridhara S, Singh BP, Arora N: Effect of proteolytic activity of Epicoccum purpurascens major allergen, Epi p1 in allergic inflammation. Clin Exp Immunol 2008; 154:162-171.

$\checkmark 5$ Tripathi P, Kukreja N, Singh BP, Arora N: Serine protease activity of Cur 11 from Curvularia lunata augments Th2 response in mice. J Clin Immunol 2009;29:292-302.
-6 King C, Brennan S, Thompson PJ, Stewart GA: Dust mite proteolytic allergens induce cytokine release from cultured airway epithelium. J Immunol 1998;161:3645-3651.

7 Bhat RK, Page K, Tan A, Hershenson MB: German cockroach extract increases bronchial epithelial cell interleukin-8 expression. Clin Exp Allergy 2003;33:35-42.

$>8$ Kauffman HF, Tomee JF, van de Reit MA, Timmerman AJ, Borger P: Protease-dependent activation of epithelial cells by fungal allergens leads to morphologic changes and cytokine production. J Allergy Clin Immunol 2000;105:1185-1193.

$>9$ Vroling AB, Duinsbergen D, Fokkens WJ, van Drunen CM: Allergen induced gene expression of airway epithelial cells shows a possible role for TNF-alpha. Allergy 2007;62: 1310-1319.

10 Liu CF, Rivere M, Huang HJ, Puzo G, Wang JY: Surfactant protein D inhibits mite-induced alveolar macrophage and dendritic cell activations through TLR signalling and DC-SIGN expression. Clin Exp Allergy 2010; 40:111-122.
11 Holt PG, Schon-Hegrad MA, Oliver J, Holt BJ, McMenamin PG: A contiguous network of dendritic antigen-presenting cells within the respiratory epithelium. Int Arch Allergy Appl Immunol 1990;91:155-159.

12 Lambrecht BN, Hammad H: Biology of lung dendritic cells at the origin of asthma. Immunity 2009;31:412-424.

13 Scarborough RM, Naughton MA, Teng W, Hung DT, Rose J, Vu TK, Wheaton VI, Turck CW, Coughlin SR: Tethered ligand agonist peptides. Structural requirements for thrombin receptor activation reveal mechanism of proteolytic unmasking of agonist function. J Biol Chem 1992;267:13146-13149.

14 Hollenberg MD: Protease-mediated signalling: new paradigms for cell regulation and drug development. Trends Pharmacol Sci 1996;17:3-6. 
15 Asokananthan N, Graham PT, Stewart DJ, Bakker AJ, Eidne KA, Thompson PJ, Stewart GA: House dust mite allergens induce proinflammatory cytokines from respiratory epithelial cells: the cysteine protease allergen, Der $\mathrm{p}$ 1, activates protease-activated receptor (PAR)-2 and inactivates PAR-1. J Immunol 2002;169:4572-4578.

16 Colognato R, Slupsky JR, Jendrach M, Burysek L, Syrovets T, Simmet T: Differential expression and regulation of protease-activated receptors in human peripheral monocytes and monocyte-derived antigen-presenting cells. Blood 2003;102:2645-2652.

-17 D’Andrea MR, Rogahn CJ, Andrade-Gordon P: Localization of protease-activated receptors-1 and -2 in human mast cells: indications for an amplified mast cell degranulation cascade. Biotech Histochem 2000;75: 85-90.

18 Chiu LL, Perng DW, Yu CH, Su SN, Chow LP: Mold allergen, Pen c13, induced IL-8 expression in human airway epithelial cells by activated protease-activated receptor 1 and 2 . J Immunol 2007; 178:5237-5244.

19 Hong JH, Lee SI, Kim KE, Yong TS, Seo JT, Sohn MH, Shin DM: German cockroach extract activates protease-activated receptor 2 in human airway epithelial cells. J Allergy Clin Immunol 2004;113:315-319.

20 Page K, Strunk VS, Hershenson MB: Cockroach proteases increase IL- 8 expression in human bronchial epithelial cells via activation of protease-activated receptor (PAR)-2 and ERK. J Allergy Clin Immunol 2003;112: $1112-1118$

-21 Sun G, Stacey MA, Schmidt M, Mori L, Mattoli S: Interaction of mite allergens Der p3 and Der $\mathrm{p} 9$ with protease-activated receptor-2 expressed by lung epithelial cells. J Immunol 2001;167:1014-1021.

-22 Lin KW, Park J, Crews AL, Li Y, Adler KB: Protease activated receptor-2 (PAR-2) is a weak enhancer of mucin secretion by human bronchial epithelial cells in vitro. Int J Biochem Cell Biol 2008;40:1379-1388.

23 Hughes VS, Page K: German cockroach frass proteases cleave pro-matrix metalloproteinase-9. Exp Lung Res 2007;33:135-150.
24 Wills-Karp M, Keane-Myers A, Gavett SH, Kuperman D: Allergen-induced airway inflammation and airway hyperreactivity in mice; in Morgan DW, Marshall LA (eds): In vivo Models of Inflammation. Basel, Birkhäuser, 1999, pp 137-158.

25 Walters DM, Breysse PN, Wills-Karp M: Ambient urban Baltimore particulate-induced airway hyperresponsiveness and inflammation in mice. Am J Respir Crit Care Med 2001;164:1438-1443.

26 Allen GL, Menendez IY, Ryan MA, Mazor RL, Wispe JR, Fielder MA, Wong HR: Hyperoxia synergistically increases TNF- $\alpha$-induced interleukin-8 gene expression in A549 cells. Am J Physiol 2000;278:L253-L260.

27 Page K, Lierl KM, Hughes VS, Zhou P, Ledford JR, Wills-Karp M: TLR2-mediated activation of neutrophils in response to German cockroach frass. J Immunol 2008; 180:63176324.

28 Ebeling C, Forsythe P, Ng J, Gordon JR, Hollenberg M, Vliagoftis H: Proteinase-activated receptor 2 activation in the airways enhances antigen-mediated airway inflammation and airway hyperresponsiveness. J Allergy Clin Immunol 2005;115:623-630.

29 Oliver BG, Lim S, Wark P, Laza-Stanca V, King N, Black JL, Burgess JK, Roth M, Johnston SL: Rhinovirus exposure impairs immune responses to bacterial products in human alveolar macrophages. Thorax 2008;63: 519-525.

30 Pylkkänen L, Gullstén H, Majuri ML, Andersson U, Vanhala E, Määttä J, Meklin T, Hirvonen MR, Alenius H, Savolainen K: Exposure to Aspergillus fumigatus spores induces chemokine expression in mouse macrophages. Toxicology 2004;200:255-263.

31 Dubourdeau M, Athman R, Balloy V, Huerre M, Chignard M, Philpott DJ, Latge JP, Ibrahim-Granet O: Aspergillus fumigatus induces innate immune responses in alveolar macrophages through the AMPK pathway independently of TLR2 and TLR4. J Immunol 2006; 177:3994-4001.

32 Bronchoalveolar lavage constituents in healthy individuals, idiopathic pulmonary fibrosis, and selected comparison groups. The BAL Cooperative Group Steering Committee. Am Rev Respir Dis 1990;141:S169S202.
33 Fitzpatrick AM, Holguin F, Teague WG, Brown LA: Alveolar macrophage phagocytosis is impaired in children with poorly controlled asthma. J Allergy Clin Immunol 2008;121:1372-1378.

-34 Gant V, Cluzel M, Shakoor Z, Rees PJ, Lee TH, Hamblin AS: Alveolar macrophage accessory cell function in bronchial asthma. Am Rev Respir Dis 1992;146:900-904.

-35 Viksman MY, Liu MC, Bickel CA, Schleimer RP, Bochner BS: Phenotypic analysis of alveolar macrophages and monocytes in allergic airway inflammation. I. Evidence for activation of alveolar macrophages, but not peripheral blood monocytes, in subjects with allergic rhinitis and asthma. Am J Respir Crit Care Med 1997;155:858-863.

36 Melgert BN, Oriss TB, Qi Z, Dixon-McCarthy B, Geerlings M, Hylkema MN, Ray A: Macrophages: regulators of sex differences in asthma? Am J Respir Cell Mol Biol 2010; 42:595-603.

37 Wan H, Winton HL, Soeller C, Tovey ER, Gruenert DC, Thompson PJ, Stewart GA, Taylor GW, Garrod DR, Cannell MB, et al: Der 1 facilitates transepithelial allergen delivery by disruption of tight junctions. J Clin Invest 1999;104:123-133.

- 38 Dommisch H, Chung WO, Rohani MG, Williams D, Rangarajan M, Curtis MA, Dale BA: Protease-activated receptor 2 mediates human beta-defensin 2 and CC chemokine ligand 20 mRNA expression in response to proteases secreted by Porphyromonas gingivalis. Infect Immun 2007;75:4326-4333.

-39 Cho HJ, Choi JY, Yang YM, Hong JH, Kim $\mathrm{CH}$, Gee HY, Lee HJ, Shin DM, Yoon JH: House dust mite extract activates apical $\mathrm{Cl}^{-}$ channels through protease-activated receptor 2 in human airway epithelia. J Cell Biochem 2010;109:1254-1263.

40 Kouzaki H, O'Grady SM, Lawrence CB, Kita $\mathrm{H}$ : Proteases induce production of thymic stromal lymphopoietin by airway epithelial cells through protease-activated receptor- 2 . J Immunol 2009;183:1427-1434.

41 Tao F, Kobzik L: Lung macrophage-epithelial cell interactions amplify particle-mediated cytokine release. Am J Respir Cell Mol Biol 2002;26:499-505. 